\title{
Persistence of Sendai Virus in a Mouse Breeder Colony and Possibility to Re-establish the Virus Free Colonies
}

\author{
Hiroshi IWAI, Toshio ITOH and Seigo SHUMIYA* \\ Central Institute for Experimental Animals 1430, Nogawa, Takatsu, Kawasaki 221, \\ and *CLEA Japan, Inc. 2-20-14, Aobadai, Meguro, Tokyo 153, Japan
}

(Received for publication: March 8, 1977)

\begin{abstract}
An epizootic of Sendai virus infection occurred in a mouse breeder colony with respiratory signs, mortality, retarded growth in young and prolonged gestation period in adults. Thereafter, the infection persisted in this colony without any clinical signs and with 90 to $100 \%$ antibody positivity in adults. Weanlings had maternal antibodies and no pneumonic lesions. Antibodies were hardly detected in 6-week-old mice with high incidence of red hepatization or congestion in their lungs, but mice over 8 weeks of age had antibody without the lesions. After isolating weanlings and pregnant mice with antibodies from the infected colony, the isolated weanlings and offspring from the isolated dams became negative for Sendai virus antibodies.
\end{abstract}

Sendai virus is one of the most prevalent viruses in laboratory rodents, The infection causes apparent clinical signs in mice, rats and guinea pigs $[1,7,10,13]$. In addition, using mice latently infected with Sendai virus in serial passages of influenza virus, the infection becomes overt and results in contamination of influenza virus strain $[3,6]$. Thus, the control of Sendai virus infection is needed as one of important diseases of laboratory animals. However, adequate information is little available on epidemiolgy of the disease.

In a barrier-sustained mouse production colony under routine monitoring for Sendai virus, an outbreak of the virus infection occurred in 1970 with temporal recognition of respiratory signs and decrease in production efficiency, and since then antibodies to Sendai virus were detectable in retired breeders until 1972 when the colony was closed.

This paper describes seroepidemiology of this epizootic and possible mechanism of perpetuation of Sendai virus in such type of breeder colonies.

\section{Materials and Methods}

Animals and the colony: All the mice used in the present studies were derived from a barrier-sustained ICR mouse colony with average production of 6,000 weanlings per week. Approximately 300 breeder candidates were left in the breeding room every week and other weanlings were transfferred to another quarter for shipping. Breeders, which were usually retired at 7 to 9 months of age, were routinely 
Table 1. Sendai virus HI antibody and gross lung lesion in mice of the infected colony

\begin{tabular}{cccccc}
\hline \multirow{2}{*}{$\begin{array}{c}\text { Age in } \\
\text { weeks }\end{array}$} & \multicolumn{2}{c}{ Exp. 1} & & \multicolumn{2}{c}{ Exp. 2} \\
\cline { 2 - 3 } \cline { 5 - 5 } & Antibody & Lung Lesion* & & Antibody & Lung Lesion* \\
\hline 3 & $4 / 10(40)^{* *}$ & $0 / 10$ & & N T*** & N T \\
4 & $1 / 10(10)$ & $0 / 10$ & $2 / 7(29)$ & $0 / 7$ \\
5 & $2 / 10(20)$ & $1 / 10(10)$ & & $3 / 9(33)$ & $2 / 10(20)$ \\
6 & $0 / 10$ & $6 / 10(60)$ & & $1 / 10(10)$ & $5 / 10(50)$ \\
7 & $2 / 10(20)$ & $4 / 10(40)$ & & $8 / 10(80)$ & $0 / 5$ \\
8 & $\mathrm{NT}$ & $\mathrm{NT}$ & & $7 / 8(88)$ & $0 / 5$ \\
9 & $\mathrm{NT}$ & $\mathrm{NT}$ & $9 / 10(90)$ & $\mathrm{NT}$ \\
10 & $10 / 10(100)$ & $0 / 10$ & $6 / 6(100)$ & $\mathrm{N} \mathrm{T}$ \\
\hline
\end{tabular}

* Congestion and / or red hepatization

** No. positive / No. tested (\%)

*** Not tested

tested for infections with Sendai virus, mouse hepatitis virus, reovirus type 3 , pneumonia virus of mice, mouse adenovirus, Mycoplasma pulmonis, Tyzzer's organism, Salmonella organism and Corynebacterium kutscheri.

Pathology: Animals moribund during epizootic and shown in Table 1 were sacrificed and examined grossly for pulmonary lesions.

Serology: Blood was obtained from either cervical vessels under ether anesthesia or retro-orbital plexus. Sera were diluted $1: 4$ with saline and heated at $56^{\circ} \mathrm{C}$ for $30 \mathrm{~min}$, and were stored at $-20^{\circ} \mathrm{C}$ until testing. Complement fixation (CF) and hemagglutination inhibition (HI) tests were performed in the microtiter system. Antigen for both tests was prepared from allantoic fluid of 12-day-old chick embryos inoculated with the MN strain of Sendai virus, which was obtained from Dr. K. Fujiwara, The Institute of Medical Science, The University of Tokyo, into the allantoic cavity at 10-day-old. Infective allantoic fluid was treated with ether and its aqu- eous fraction was used as antigen. AntiSendai virus mouse sera were also provided through the courtesy of Dr. Fujiwara.

$\mathrm{CF}$ test was performed according to Kolmer's method. Test sera were serially diluted with saline containing $1: 4$ dilution of pooled mouse sera having no antibodies to Sendai virus. Four units of antigen and two full units of complement were added, and the plates were placed at $4^{\circ} \mathrm{C}$ overnight. Then, the hemolytic system was added, and incubation was made at $37^{\circ} \mathrm{C}$ for $60 \mathrm{~min}$. Antibody titers were determined as the reciprocal of the highest dilution showing inhibition of hemolysis at $75 \%$ or more. Titers $1: 4$ or greater were regarded as positive.

For HI test, sera were diluted in PBS containing $0.5 \%$ bovine serum albumin and four units of antigen were added. After incubation at $37^{\circ} \mathrm{C}$ for $30 \mathrm{~min}, 1 \%$ suspension of guinea pig red blood cells were added, and the plates were hold at $4^{\circ} \mathrm{C}$ for $60 \mathrm{~min}$. Titers of $1: 8$ or higher were regarded as positive, and antibody titers were expressed as the reciprocal of 


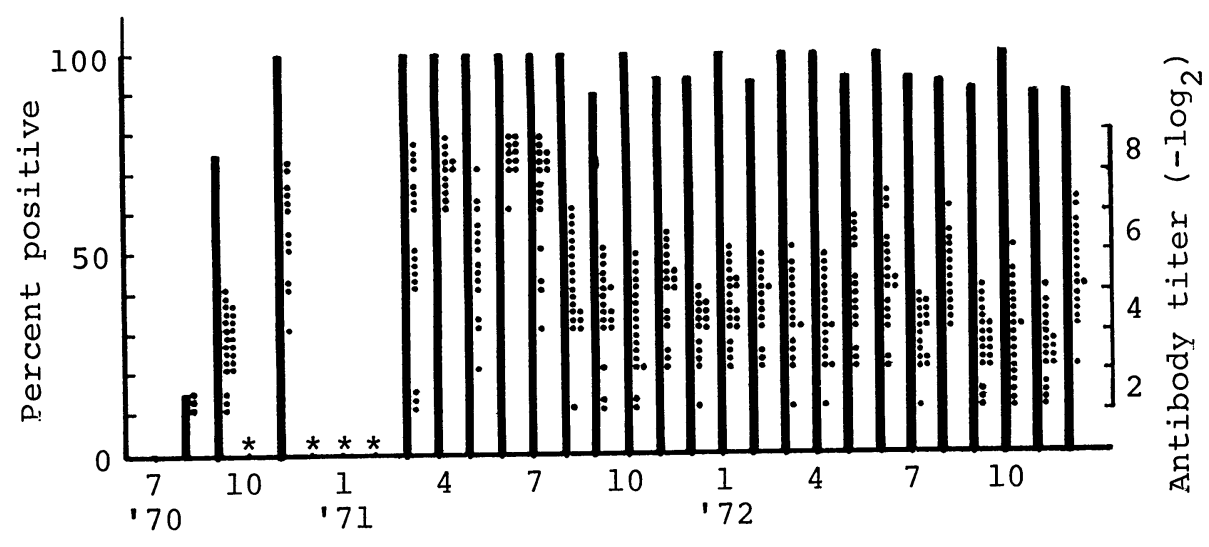

Black bar: Percent positive *: Not tested
Dot: Individual antibody titer

Fig. 1. Sendai virus CF antibodies in retired breeder ICR mice of an infected colony

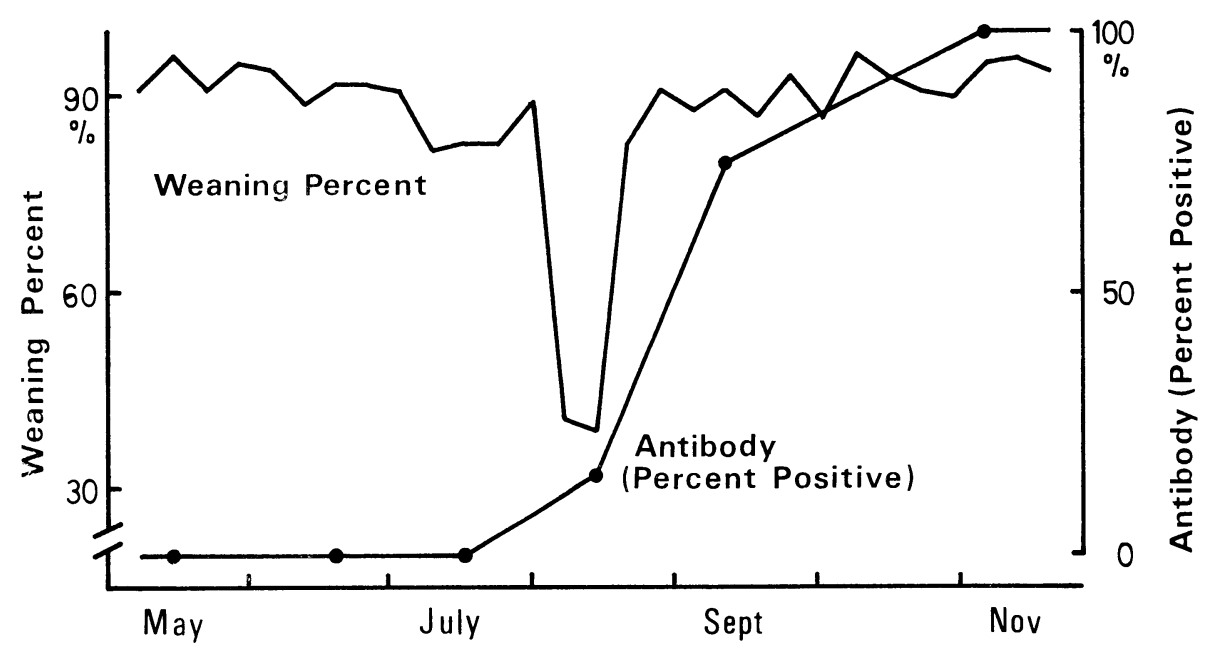

Fig. 2. Weaning percent and sendai virus $\mathrm{CF}$ antibody positivity in retired breeder mice before and after the outbreak of the infection

the highest diltuion of the serum showing hemagglutination inhibition.

\section{Results}

For routine monitoring of Sendai virus antibody, approximately 20 retired breeders, about $2 \%$ of the total breeders discarded per month, were tested every month. As shown in Fig. 1, prior to August, 1970, about 800 sera tested were negative for $\mathrm{CF}$ antibodies to Sendai virus. However, $3(15 \%)$ out of 20 serum samples collected in August, 1970, were positive, and in September and November, $75 \%$ (30 out of 40) and $100 \%$ (19 out of 19), were found to be positive, respectively. Thereafter, the infection had persisted in the colony until the colony was closed. HI antibody patte- 
rns revealed after February, 1972, were essentially similar to those observed in the CF test.

As shown in Fig. 2, sudden occurrence of respiratory disease, some death and cannibalism by dams, which were responsible for decrease in weaning rate $\%$ of numbers of weanlings to numbers of neonates nursed), prolonged gestation periods and decrease in litter size were followed by increasing positsvity of Sendai virus antibodies in adult mice. Congestion and red hepatization of lungs were observed in moribund mice examined during epizootic. Within about 4 weeks the epizootic was over and no such findings were recognized.

To investigate age- and quarter-dependency of the infection, 3- to 10-week-old mice kept in different quarters were examined for antibody and lung lesions. Ten mice each reared in a quarter for shipping since 3 weeks of age were examined at different ages as shown in Exp. 1 of Table 1. On the other hand, mice of different ages remained in the breeding room were also examined (Exp. 2).
In Exp. 1, 40\% of animals were shown to have antibodies at 3 weeks of age, and none were positive at 6 weeks of age. At 10 weeks, however, antibodies were detected in $100 \%$ of mice examined. Red hepatization of lungs were observed only in animals at 5, 6 and 7 weeks of age. Similar results were obtained in Exp. 2.

To determine whether weanlings are protected from Sendai virus infection by maternal antibodies or actively infected, 3- to 4-week-old mice were tansferred from the infected colony and reared in a vinyl isolator or in an animal room previously disinfected with formaldehyde gas, and they were examined for Sendai virus antibodies 3 or more weeks after isolation. As shown in Exp. 1 and 3 of Table 2, mice became all negative for antibodies at 6 to 14 weeks of age. In Exp. 2, however, in which 30 mice from an isolator were tested at 9 weeks of age, $93 \%$ and $83 \%$ of animals were positive in $\mathrm{CF}$ and $\mathrm{HI}$ tests, respectively.

Pregnant mice having Sendai virus antibodies were placed in a vinyl isolator just before delivery and the serum antib-

Table 2. Sendai virus antibody in mice isolated from the infected colony into an environment free from the virus at 3 to 4 weeks of age

\begin{tabular}{ccccc}
\hline Exp. & $\begin{array}{c}\text { No. Mouse } \\
\text { Isolated }\end{array}$ & $\begin{array}{c}\text { Age in Weeks } \\
\text { at Test }\end{array}$ & $\begin{array}{c}\text { CF } \\
\text { Antibody }\end{array}$ & $\begin{array}{c}\text { HI } \\
\text { Antibody }\end{array}$ \\
\hline \multirow{2}{*}{1} & 30 & 7 & $0 / 27^{*}$ & $\mathrm{~N} \mathrm{~T}^{* *}$ \\
& & 14 & $0 / 22$ & $\mathrm{~N} \mathrm{~T}$ \\
2 & 30 & 4 & $\mathrm{~N} \mathrm{~T}$ & $12 / 30$ \\
& & 9 & $27 / 29$ & $24 / 29$ \\
3 & 30 & 3 & $4 / 21$ & $10 / 18$ \\
& & 6 & $0 / 19$ & $0 / 19$ \\
& & 10 & $0 / 30$ & $0 / 30$ \\
\hline
\end{tabular}

* No. positive / No. tested

** Not tested 
Table 3. Dams' antibody titers and persistence of maternal antibodies in their offsprings

\begin{tabular}{|c|c|c|c|c|c|c|c|c|c|c|c|c|c|c|c|c|c|}
\hline \multirow{4}{*}{ Exp. } & \multirow{4}{*}{$\begin{array}{c}\text { Mouse } \\
\#\end{array}$} & \multicolumn{8}{|c|}{ CF Antibody } & \multicolumn{8}{|c|}{ HI Antibody } \\
\hline & & \multirow{3}{*}{ Dam* } & \multicolumn{7}{|c|}{ Offspring** } & \multicolumn{8}{|c|}{ Offspring } \\
\hline & & & \multicolumn{7}{|c|}{ Age in Weeks } & Dam* & \multicolumn{7}{|c|}{ Age in Weeks } \\
\hline & & & 3 & 4 & 5 & 6 & 10 & 15 & 21 & & 3 & 4 & 5 & 6 & 10 & 15 & 20 \\
\hline \multirow[t]{7}{*}{1} & 13 & - & $2^{* * *}$ & - & - & & $-* *$ & & & 3 & 4 & - & - & & - & & \\
\hline & 26 & 2 & 3 & - & - & & - & & & 3 & 4.3 & - & - & & - & & \\
\hline & 24 & 2 & 3 & - & - & & - & & & 4 & 5.7 & 3.7 & - & & - & & \\
\hline & 12 & 3 & 2.7 & - & - & & - & & & - & 3 & - & - & & - & & \\
\hline & 21 & 3 & 3 & - & - & & - & & & 5 & 5 & 3 & - & & - & & \\
\hline & 28 & 3 & 3 & - & - & & - & & & 5 & 6 & 3 & - & & - & & \\
\hline & 11 & 4 & 3.5 & - & - & & - & & & 3 & 3.3 & - & - & & - & & \\
\hline \multirow[t]{5}{*}{2} & 16 & 5 & 3 & & & - & - & - & - & 6 & 4.5 & & & 3 & - & - & - \\
\hline & 15 & 5 & 4 & & & 2 & - & - & - & 8 & 6.4 & & & 5 & 4.7 & 4 & - \\
\hline & 12 & 6 & 4 & & & 2.6 & - & - & - & 8 & 6 & & & 5 & 5 & 3 & - \\
\hline & 7 & 7 & 5 & & & 3 & - & - & - & 8 & 6 & & & 5 & 4 & - & - \\
\hline & 14 & 7 & 6 & & & 3.9 & 2.6 & - & - & 9 & 6.6 & & & 5 & 5.6 & - & - \\
\hline
\end{tabular}

* Titer at weaning of their offsprings ( 3 weeks of age)

** Mean titer of 3 to 6 mice

*** Reciprocal of $\log _{2}$ titer

**** Not detected

odies of their offsprings were checked at intervals after weaning in order to determine whether the offsprings become seronegative for Sendai virus.

In the first experiment, in which the dams delivered at 12 weeks of age, CF and $\mathrm{HI}$ titers of the offsprings at 3 weeks of age were equivalent to those of their dams as shown in Table 3. At 4 weeks of age, however, $\mathrm{CF}$ antibodies of offsprings became undetectable. The HI titer gradually decreased slower than CF titer, and at 5 weeks, none were positive.

The same type of experiment was performed using about 6- month-old mice inoculated intraperitoneally twice with 0.1 $\mathrm{ml}$ of $4 \mathrm{CF}$ units of ether inactivated Sendai virus antigen at mating and one week after partrition. In this case, the $\mathrm{CF}$ and
HI antibody titers of dams were $1: 32$ to $1: 512$, and offsprings were shown to have persisting antibodies in higher titer, which were consequently eliminated by 21 weeks of age. Although the data are not included in Table 3, some of these offsprings were shown to be positive at 21 weeks of age after exposing to an animal room contaminated with Sendai virus.

\section{Discussion}

In a mouse breeder colony in which overt disease suddenly occurred with respiratory disease, mortality, prolonged gestation periods, decreases in litter size, cannibalism by dams and retarded growth of sucklings, antibodies to Sendai virus were detected in 15\% of retired breeder mice tested at the height of the outbreak 
and then, $100 \%$ of mouse sera tested were positive for the antibody after the disappearance of overt disease. During the observation period, the colony was serologically free from other agents known to cause respiratory infections, e.g. Mycoplasma pulmonis, reovirus type 3 and pneumonia virus of mice.

Respiratory disease with mortality, retarded growth and increased cannibalism have been reported in naturally occurring Sendai virus infections $[1,7,10,13]$. Prolonged gestation periods and decreases in litter size were observed in experimental Sendai virus infection in rats by Coid and Wardman [2]. However, some infection with Sendai virus in mice were observed without any clinical signs $[3,11]$. It is conceivable that the overt disease may result when the virus is of higher virulence and/or mice are highly susceptible because of their genetic badkground [9], age [12], physiological condition, etc.

After the epizootic, antibodies against Sendai virus were detected in retired breeder mouse sera during two years' observation period, indicating that the virus was persisting in this colony. The similar observations were also reported by Parker and Reynords [11] and Iida et al. [8], suggesting that the presence of susceptible mice might result the perpetuation of the virus in a colony with high positivity of antibodies.

As shown in Table 1, weanlings had maternal antibodies that disappeared by 5 to 6 weeks of age. Around this age, there was high incidence of gross lesions in lungs although the animals were apparently healthy, indicating that virus multiplied in the respiratory tract of these young animals with declining maternal anț̣bodies. Fukumi et al. [4] also observed gross lung lesions in apparently normal mice infected with Sendai virus.

After the isolation of weanlings from infected environment, no antibody was found, while almost all mice left in the infected colony became sero-positive at 8 to 10 weeks of age. This indicates that weanlings carry no virus probably because of maternal antibodies, as suggested Iida et al. [8]. In one experiment in which antibody titers in retired breeders had been low, weanlings became to have antibodies despite of isolation.

The mechanism of persistence of the Sendai virus in this mouse colony could be assumed as follows. The virus failed to propagate enough to produce overt disease or antibody in weanling mice having maternally derived antibodies. With declining antibodies, however, such mice became susceptible to the virus, and almost all mice were thus immunized before or around 8 weeks of age, though the infection never developed so much and virus would be eliminated soon. Indeed, in this colony, about 300 breeder candidates were supplied every week, they might constitute new susceptible hosts that contributed to the perpetuation of Sendai virus within the colony.

Fukumi et al. [4] and Parker and Reynords [11] reported that Sendai antibodies in mouse colonies became undetectable after persisting for 3 to 7 months. The difference between the results of these workers and of the present paper may be due to the difference in size of colony as well as the method of providing breeder candidates. 
By the isolation of weanlings or pregnant mice from a comtaminated colony with Sendai virus, they or their offsprings became negative for Sendai antibodies, indicating possibility of obtaining mice free from the virus. This method may be useful for establishing non-infected breeding groups separated from contaminated colony without difficulties such as Caesarean delivation and foster nursing procedure. Moreover, it may be applicable to laboratory animals other than mouse as well as to viral infections other than Sendai virus.

\section{Acknowledgments}

The authors wish to thank Dr. Kosaku Fujiwara, of The Institute of Medical Science, The University of Tokyo, for providing the Sendai virus strain $\mathrm{MN}$ and anti-Sendai mouse sera, and for his advice on preparation of the manuscript.

The authors also express their gratitude to Mrs. T. Takahashi, and Misses M. Suzuki, J. Yamanaka and Y. Ishihara for technical assistance.

\section{References}

[1] Bhatt, P. N. and Jonas, A. M. (1975). An epizootic of Sendai infection with mortality in a barrier-maintained mouse colony. Amer. J. Epidemiol., 100, 222-229.

[2] Coid, C. R. and Wardman, G. (1972). The effect of maternal respiratory disease induced by parainfluenza type 1 (Sendai) virus on foetal development and neonatal mortality. Med. Microbial. Immunol., 157, 181-185.

[3] Fukumi, H., Nishikawa, F. and Kitayama, T. (1954). A pneumotropic virus from mice causing hemagglutination. Jap. J. Med. Sci. Biol., 7, 345-365.

[4] Fukumi, H., Mizutani, H., Takeuchi, Y., Tajima, Y., Imaizumi, K., Tanaka, T. and Kaneko, J. (1962). Studies on Sendai virus infection in laboratory mice. Jap. J. Med. Sci. Biol., 15, 153-163.

[5] Fujiwara, K., Takenaka, S. and Shumiya, S. (1976). Carrier state of antibody and viruses in a mouse breeding colony persistently infected with Sendai and mouse hepatitis viruses. Lab. Anim. Sci., 26, 153159.

[6] Grunert, R. R. (1967). Isolation of Sendai virus as a latent respiratory virus in mice. Lab. Anim. Care, 17, 153-159.

[7] Hayashi, S. (1961). Studies on the infection of Myxovirus para-influenzae 1 ( $\mathrm{HVJ}$ ) in the small experimental animals. Virus, 11, 108-119.

[8] Iida, T., Tajima, M. and Murata, Y. (1973). Transmission of maternal antibodies to Sendai virus in mice and its significance in enzootic infection. J. Gen. Virol., 18, $247-258$.

[9] Lindenmann, J., Lane, C. A. and Hobson, D. (1963). The resistance of A $2 \mathrm{G}$ mice to myxoviruses. J. Immunol., 90, 942-951.

[10] Makino, S., Seko, S., Nakao, H. and Mikazuki, K. (1973). An epizootic of Sendai virus infection in a rat colony. Exp. Animals, 22, 275-280.

[11] Parker, J. C. and Reynords, R. K. (1968). Natural history of Sendai virus infection in mice. Amer. J. Epidemiol., 88, 112-125.

[12] Sawicki, L, (1961). Influence of age of mice on the recovery from experimental Sendai virus infection. Nature, 192, 12581259.

[13] Ward, J. M. (1974). Naturally occurring Sendai virus disease of mice. Lab. Anim. Sci., 24, 938-942. 


\title{
マウス繁殖コロニーにおけるセンダイウイルスの 存続様式について
}

\author{
岩井 浤・伊藤豊志雄・朱 宮 正 剛*
}

財団法人実験動物中央研究所

*日本クレア株式会社

ICRマウス繁殖コロニーでセンダイウイルス感染が起 った。主として幼若動物の呼吸器症状, 死亡, 発育不良, 親による喰殺が顕著で, 妊娠マウスでは出産の遅延, 産 仔数の減少が観察された。抗体をもつマウスがふえるに つれ，上記諸症状はみられなくなったが，コロニー閉鎖 まで約 2 年半にわたり退役マウスには $90 \sim 100 \%$ の割合 で抗体が検出された。離乳マウスには移行抗体が検出さ
れ, 肺病変は認められなかった。6 週令のものでは抗体 はほとんど検出されず，肺の肝変化病变をもつものが多 かった。 8 週令以上の動物ではほとんど全例が抗体をも ち, 肝変化病変はみられなかった。離乳、ウスや妊娠、 ウスを感染コロニーから隔離しある期間飼育すると，抗 体のない動物（隔離された離乳マウス拉よび妊娠マウス から産れた次世代マウス）が得られた。 